\title{
Analysis of Behaviorism Learning Theory, STEM Learning Model and Gamification
}

\author{
M. Givi Efgivia ${ }^{1 *}$, Anggi Arista ${ }^{2}$, Reni Kurniawati ${ }^{3}$, Kasori $^{4}$ \\ ${ }^{1}$ Postgraduate Educational Technology, University of Ibnu Khaldun Bogor Indonesia \\ ${ }^{2}$ SMK Muhammdiyah Tajurhalang Bogor, Indonesia \\ ${ }^{3}$ SMPIT AL KAHFI Bogor, Indonesia \\ ${ }^{4}$ MA Pesantren Ibnu Taimiyah Bogor, Indoneisa \\ *Corresponding author email: mgivi@uika-bogor.ac.id
}

\begin{abstract}
Learning theory will be related to curriculum making or curriculum design. By studying learning theory, it is possible to observe the behavior of students. While the behaviorism approach focuses on guiding students to achieve predetermined learning outcomes. Learning is considered to occur when students succeed in achieving the expected results and the STEM learning model is an approach in learning that integrates two or more fields of knowledge contained in STEM while the gamification learning model is a learning approach using elements in games or video games. Therefore, this study aims to 1) understand learning theory, 2) behaviorism theory and its applications, 3) understand STEM learning models, 4) understand gamification learning models. The research method uses qualitative research methods (library research). The conclusions from the four materials discussed are studying learning theory which consists of behaviorism theory, cognitivism theory, humanistic theory, and constructivism theory and studying behavioristic learning theory states that learning changes behavior, which means the learning process occurs when student behavior has changed. If the student has not responded, then the student's behavior has not changed, so it is not said to be learning. And studying STEM learning models which is an approach in learning that integrates two or more fields of science and Gamification models, namely models with learning approaches using elements in games or video games
\end{abstract}

Keywords: Learning Theory; Behaviorism Theory; STEM, Gamification Learning Model

\section{INTODUCTION}

Learning is a conscious effort process carried out by individuals for a change from not knowing to knowing, from not having the attitude to being right, from being unskilled to being skilled at doing something. Theory is a set of principles composed of certain events in the real world stated by McKeachie in Grendel 1991: 5 (Hamzah Uno, 2006:4). Meanwhile, Hamzah (2003:26) states that theory is a set of prepositions in which it contains ideas, concepts, procedures and principles consisting of one or more variables that are interconnected with each other and can be studied, analyzed and tested and proven true. From the two opinions above, theory is a set of principles about events which contain ideas, concepts, procedures and principles that can be studied, analyzed and tested for truth. Learning theory is a theory in which there are procedures for applying teaching and learning activities between teachers and students, designing learning methods and models that will be carried out in the classroom and outside the classroom.

\section{METHOD}

The research method is using qualitative research (library research). This research process is carried out by researching and analyzing references from baboon books, supporting books, websites, youtube, and group discussions related to four themes, namely learning theory, behaviorism theory and its application, STEM learning models and gamification.

\section{RESULT AND DISCUSSION}

3.1. Behaviorism Theory and Its Application

Behavioristic learning theory states that learning changes behavior. Behaviorist experts say that the learning process occurs when the student's behavior has changed, if the student has not responded, then the student's behavior has not changed. And in behavioristic learning theory, if the student's 
behavior has not changed, a punishment system will apply.

Examples of the application of behaviorism theory are: Determining instructional goals, analyzing the current environment including identifying student "entry behavior" (students' initial knowledge), Determining subject matter (subjects, topics), Breaking subject matter into small parts ( sub-topics, sub-topics), Presenting subject matter, Providing stimuli in the form of: questions, tests, exercises, assignments, Observing and reviewing the responses given, Providing reinforcement (positive or negative), Providing new stimuli, Observing and reviewing the response given (evaluating learning outcomes), providing reinforcement, and so on.

\subsubsection{Behaviorism Theory Based on Three} Characters and Their Applications

As the name implies, the behavioristic approach focuses on guiding students to achieve predetermined learning outcomes. Learning is considered to occur when the learner achieves these expected outcomes, which are designed to meet the learning objectives of the eLearning course. Some figures in behavioristic learning theory:

Pavlov's Theory

Pavlov developed a conditioned behavior study, followed by Classical Conditioning. He used research from dog observations. Dogs will salivate when they see food. This theory became the basis for the development of Behaviorism psychology, as well as laid the foundations for the development of theories about learning.

John Watson Theory

Learning is a process of interaction between stimulus and response, but the intended stimulus and response must be in the form of observable and measurable behavior. According to Watson and other experts believe that human behavior is the result of genetic inheritance and environmental or situational influences. Behavior is controlled by irrational forces.

Skinner Theory

Skinner introduced a new term into the Law of Effect - Reinforcement. Reinforced behaviors tend to be repeated (i.e., reinforced); behaviors that are not reinforced are likely to die or be annihilated (i.e., attenuated). Skinner (1948) studied operant conditioning by conducting experiments using animals he placed in a 'Skinner Box' similar to Thorndike's puzzle box. Skinner identified three types of responses, or operands

Application

Teacher-led and designed learning, Repetition, practice and practice, Learning can be measured and defined by learning objectives, Q\&A (stimulusresponse) with instant feedback, External motivation, Predefined chain steps to follow, Learner assessed primarily through testing and instructional cues

\subsection{STEM Learning Model}

STEM stands for an interdisciplinary learning approach between Science, Technology, Engineering and Mathematics. According to the expert opinion, Torlakson (2014: 7) states that the approach of these four aspects is a harmonious pair between problems that occur in the real world and also problem-based learning. In addition, according to khairiyah (2019: 28). The STEM learning model approach consists of discovery learning, inquiry learning, problem based learning, and the learning cycle.

3.2.1. STEM (Science, Technology, Engineering and Mathematics) Learning Model.

STEM stands for an interdisciplinary learning approach between Science, Technology, Engineering and Mathematics. According to the expert opinion, Torlakson (2014: 7) states that the approach of these four aspects is a harmonious pair between problems that occur in the real world and also problem-based learning. In addition, according to khairiyah (2019: 28). The following discusses various learning models that can be applied using the STEM Approach in learning:

3.2.1.1. Discovery learning, emphasizes the discovery of previously unknown concepts or principles with a focus on problems engineered by the teacher. The application of the DiscoveryLearning learning model emphasizes the role of the teacher as a mentor by providing opportunities for students to learn actively. In the 2013 Curriculum training module, it is explained that the discovery learning syntax consists of 6 phases as follows:

$\checkmark$ Stimulation (stimulation / giving stimulation)

$\checkmark$ Problem statement (statement/problem identification)

$\checkmark$ Data collection (Data collection).

$\checkmark$ Data Processing (Data Processing)

$\checkmark$ Verification

$\checkmark$ Generalization (draw conclusions/generalizations)

This stage is the process of drawing a conclusion that can be used as a general principle and applies to all events or the same problem.

3.2.1.2. Inquiry Learning, focuses on students finding problems so that they must mobilize all their knowledge and skills to get findings in the problem through the research process. Sanjaya (2014) states 
$\checkmark$ Orientation

that the steps of the Inquiry learning model are as follows:

$\checkmark$ Formulating the Problem

$\checkmark$ Formulate hypotheses.

$\checkmark$ Collecting data

$\checkmark$ Testing the hypothesis

$\checkmark$ Formulate conclusions.

3.2.1.3. Problem Based Learning model, is learning that uses various thinking abilities of students individually and in groups as well as the real environment to overcome problems so that they are meaningful, relevant, and contextual. Aris Shoimin (2014:131) suggests that the steps in the Problem Based Learning learning model are as follows:

$\checkmark$ The teacher explains the learning objectives. Describe the logistics required. Motivate students to engage in selected problem solving activities.

$\checkmark$ The teacher helps students define and organize learning tasks related to the problem (setting topics, assignments, schedules, etc.).

$\checkmark$ The teacher encourages students to collect appropriate information, experiments to get explanations and problem solving, data collection, hypotheses, and problem solving.

$\checkmark$ The teacher helps students in planning and preparing appropriate works such as reports and helps them with various tasks with their friends.

$\checkmark$ The teacher helps students to reflect or evaluate their investigations and the processes they use.

3.2.1.4. Learningcycle, Bybee \& Landes, 1990 explains that the $5 E$ learningcycle model is oriented towards constructivist learning (constructivist approach) which pays attention to the experience and prior knowledge of students and aims to improve students' conceptual understanding. This model has 5 syntaxes/stages as follows: Engagement, Exploration, Explanation, Elaboration, Evaluation

\subsection{Gamification Learning Model}

Gamification is a learning approach using elements in games or video games with the aim of motivating students in the learning process and maximizing feelings of enjoyment and engagement in the learning process. 2. The steps to apply the gamification learning model, including the following:

$\checkmark$ Break the subject matter into specific sections. Give a quiz at the end of each section and award participants/students with a virtual badge if they pass the quiz.

$\checkmark$ Separate the material into different and tiered levels. So, as their learning progresses, students get badges and higher levels are unlocked so they can learn new material.

$\checkmark$ Record the score obtained in each section. This is intended for students to focus on improving their overall score.

$\checkmark$ Give a reply (reward)

$\checkmark$ Make the levels/levels sensitive to date or time, so they have to check every day, every week, or every month for new challenges. Create task groups so students can collaborate together to complete projects.

$\checkmark$ Give students an incentive to share and comment on their friends' work. This encourages a culture of knowledge sharing.

$\checkmark$ Surprise with extra bonus rewards when students pass new challenges.

$\checkmark$ Create artificial stress by using 'countdown' on various quizzes. This method will make students face challenges with time constraints.

\subsubsection{Gamification Learning Model}

Nick Pelling first used the term gamification in 2002 in a presentation at a TED (Technology, Entertainment, Design) event. Gamification is a learning approach using elements in games or video games with the aim of motivating students in the learning process and maximizing feelings of enjoyment and engagement in the learning process. The steps for implementing the gamification learning model are as follows:

$\checkmark$ Break the subject matter into specific sections. Give a quiz at the end of each section and award participants/students with a virtual badge if they pass the quiz.

$\checkmark$ Separate the material into different and tiered levels. So, as their learning progresses, students get badges and higher levels are unlocked so they can learn new material.

$\checkmark$ Record the score obtained in each section. This is intended for students to focus on improving their overall score.

$\checkmark$ Give a reply (reward)

$\checkmark$ Make the levels/levels sensitive to date or time, so they have to check every day, every week, or every month for new challenges. Create task groups so students can collaborate together to complete projects.

$\checkmark$ Give students an incentive to share and comment on their friends' work.

$\checkmark$ Surprise with extra bonus rewards when students pass new challenges.

$\checkmark$ Create artificial stress by using 'countdown' on various quizzes. This method will make students face challenges with time constraints. 


\section{CONLUSION}

Behavioristic learning theory states that learning changes behavior. Examples of the application of behaviorism theory are: Determining instructional goals, Analyzing the current environment including identifying student "entry behavior" (students' initial knowledge), Determining subject matter (subjects, topics), Breaking subject matter into small parts ( sub-topics, sub-topics), Presenting subject matter, Providing stimuli in the form of: questions, tests, exercises, assignments, Observing and reviewing the responses given, Providing reinforcement (positive or negative), Providing new stimuli, Observing and reviewing the response given (evaluating learning outcomes), providing reinforcement, and so on.

STEM stands for Science, Technology, Engineering and Mathematics. Torlakson (2014:7) states that the approach of these four aspects is a harmonious match between problems that occur in the real world and also problem-based learning. In addition, Khairiyah (2019: 28) the STEM learning model approach consists of discovery learning, inquiry learning, problem based learning, and learning cycle learning models. Gamification is a learning approach using elements in games or video games with the aim of motivating students in the learning process and maximizing feelings of enjoyment and engagement in the learning process.

\section{REFERENCES}

[1]. Torlakson, Tom, et al. (2014). Innovate : A blueprint for science, Technology, Engineering, and Mathematict in
California Public Education, Clifornia. Diakses dari http://www.cde.ca.gov/pd/ca/sc/dokuments/in novate.pdf

[2]. Khairiyah, E. 2019, Pendekatan Science, Technology, Engineering, dan Mathematics (STEM). Guepedia.

[3]. Sanjaya, Wina. (2014). Startegi Pembelajaran, Jakarta : KencanaPrenada Media Group.

[4]. Shoimin, Aris. (2014). 68 Model Pembelajaran Inovatif Dalam Kurikulum 2013, Yogyakarta: ARRUZZ MEDIA

[5]. Budiningsih, Asri. 2008. Teori Belajar dan Motivasi. Universitas Negeri Jakarta.

[6]. Hamzah, Uno. 2006. Perencanaan Pemberian Pembelajaran. Jakarta :PT Bumi Aksara. Hamzah. 2003. Proses Belajar Mengajar. Jakarta : Bumi Aksara https://www.simplypsychology.org/operantconditioning.html
[7]. https://elearningindustry.com/behaviorismininstructional-design-for-elearning-whenand-how-to-use https://plato.stanford.edu/entries/behaviorism/

[8]. https://www.learningtheoies.com/gamification-in-education.html https://tophat.com/blog/gamificationeducation-class/ 